\title{
Study on the Relationship between Employee Emotional Labor and Customer Response
}

\author{
Qing Jun Wang ${ }^{1, a} \quad$ Lan Feng ${ }^{2, b}$ \\ ${ }^{1,2}$ School of Hefei University of Technology Hefei 230009,China

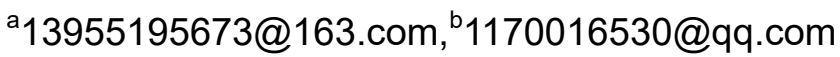

\begin{abstract}
Keyword: Emotional labor. Customer reactions. Employee Emotional labor Acting;
\end{abstract}
\begin{abstract}
This paper constructs the service personnel hypothesis model of emotional labor and customer response, by refer to literature. The customer response scale was optimized. Using SPSS data analysis software, data is analyzed to verify the service personnel between emotional labor and customer response hypothesis model is established, such as descriptive statistics analysis, correlation analysis and regression analysis.
\end{abstract}

\section{Introduction}

Communication is the key to the service,but there is no fixed way to communicate with people, it is very mentally challenging and often makes people feel exhausted ${ }^{[1]}$. Service personnel often nee $\mathrm{d}$ to deal with the case-bycase situation, this is a challenging and suffering thing to the frontline serv ice staff. But now, service personnel's tension, stress, job burnout and other issues in the communic ation process, which is generated by the emotional labor, has not gotten administrative concern.

Therefore, this paper, based on the presentsituation and problems in the services staff emotional 1 abor and on the status of research in emotional labor by Chinese scholars, explores the relation betw een service personnel emotional labor and customer response by literal translating and optimizing th e "Emotional Labor Table", in order to further deepen the existing framework and theoretical knowl edge and offer reference to the enterprise in the recruitment, training and management, then improv e the efficiency of enterprises.

\section{Theoretical Basis and Research Hypotheses}

Emotional labor Measure.Since the concept of emotional labor is presented, as scholars have di fferent views and opinions on the concepts and dimensions of emotional labor, they developed tools from different angles to measure it. Adelmann and Hochschild lead in the preparation of the emoti onal labor scale, the exploition of scale is to promote the study of emotional labor and scale develop ment ${ }^{[2]}$. Grandey (2003) exploited the emotional labor measurement tool from the two-dimensional structure of emotional labor, which contains two subscales of deep acting and shallow behavior ${ }^{[3]}$. Chau (2009) developed two subscales including mood disorders (14 projects) and emotional effort ( 5 items) ${ }^{[4]}$, there are five emotional effort items to measure deep impersonation, he derived the inter nal consistency coefficient of mood disorders and emotional efforts two subscales were 0.80 and 0.6 9.

Emotional labor scale development makes the emotional labor has been quantified, provides an $\mathrm{i}$ mportant tool for empirical research, and promotes the emotional labor development from concept $t$ o operation.However, the above-mentioned scales can see the current scale for measuring emotional labor has not yet formed a unified point of view, and this is mainly because the scholars developed scales based on the different concepts and structures of emotions labor.

Emotional labor impact on the customer. This paper based on the emotional labor researches a nd scales at home and abroad optimizes the scale of service staffs emotional labor and customer res ponse. And using SPSS19.0 statistical software to process collected data, and then explore the relati onship between emotional labor and customer response. Hypothesis is the following:

Hypothesis1aEmployee deep acting relates positively to perceived customer orientation.

Hypothesis1bEmployee surface acting relates negatively to perceived customer orientation. 
Hypothesis 2aEmployee deep acting relates positively to perceived service quality.

Hypothesis2bEmployee surface acting relates negatively to perceived service quality.

Hypothesis 5 Perceived customer orientation relates positively to perceived service quality.

Hypothesis 6 Perceived customer orientation relates positively to customer loyalty intentions.

Hypothesis 7 Perceived service quality relates positively to customer loyalty intentions.

Hypothesis3a. The greater customers' deep acting detection accuracy, the more strongly positive the relationship between employee deep acting and perceived customer orientation.

Hypothesis $3 b$. The greater customers' deep acting detection accuracy, the more strongly positive the relationship between employee deep acting and perceived service quality.

Hypothesis4a. The greater customers' surface acting detection accuracy, the more strongly negative the relationship between employee surface acting and perceived customer orientation.

Hypothesis $4 b$. The greater customers' surface acting detection accuracy, the more strongly negative the relationship between employee surface acting and perceived service quality.

\section{Research design}

Sample. In this study, we have chosen a number of Hefei service businesses, such as restaurants, stores, supermarkets. We distributed 170 questionnaires, using $\mathrm{T}$ test to weed out abnormal samples and get 166 valid questionnaires. Among them, the number of samples in the age between 21-25 years of age accounted for $47 \%$, Junior high or high school education samples accounted for $74.1 \%$. Customers are mostly aged $21-30$ years, $73.5 \%$ of the total sample. And their qualifications are mostly specialist level.

Variables Measure.Data analysis showed that: "Customer response scale" Cronbach's coefficient was 0.825 ,more than 0.8 , indicating that high levels of internal consistency of the Scale. This shows that all questions of customer response scale has good reliability; Calculating an average extracted variance of each factor (AVE)based on the value of the load factor, each variable factor load factor between $0.553-0.903$, greater than 0.5 , indicating a good convergent validity of the scale.

\section{Hypothetical Model Test}

Correlation analysis of employee emotional labor and customer response. First of all, we have variable correlation analysis, the results shown that employee deep acting relates positively to perceived customer orientation, where $\rho=0.442, \mathrm{P}=0.000 \leq 0.05$, the results support the hypothesis 1a;Employee surface acting doesn't relate negatively to perceived customer orientation, where $\rho=-0.095, P=0.395 \geq 0.05$, the results do not support the hypothesis $1 b$;Employee deep acting relates positively to perceived service quality, where $\rho=0.399, \mathrm{P}=0.000 \leq 0.05$, the results support the hypothesis $2 \mathrm{a}$;Employee surface acting doesn't relate negatively to perceived service quality, where $\rho=0.014, \mathrm{P}=0.901 \geq 0.05$, the results do not support the hypothesis $2 \mathrm{~b}$;Perceived customer orientation relates positively to perceived service quality, where $\rho=0.567, \mathrm{P}=0.000 \leq 0.05$, the results support the hypothesis 5; Perceived customer orientation relates positively to customer loyalty intentions, where $\rho=0.526, P=0.000 \leq 0.05$, the results support the hypothesis 6 ;Perceived service quality relates positively to customer loyalty intentions, where $\rho=0.579, P=0.000 \leq 0.05$, the results support the hypothesis 7 .

\section{Regression analysis of employee emotional labor and customer response .}

(1)The relation between Perceived customer orientation and Employee deep acting- Customer perceptions of employee deep acting as the moderator

As can be seen from Table1, the average error of a regression model 1 is $2.461, \mathrm{~F}$ value of 12.731, $\mathrm{P}$ value close to 0 ; the average error of a regression model 2 is $1.849, \mathrm{~F}$ value of $9.841, \mathrm{P}$ value close to 0 ; This means that it is suitable for regression analysis of "Customer perceptions of employee deep acting" and "customer perception orientation" and "deep acting", and the two models have passed the hypothesis testing. 
Tab 1 Perceived customer orientation and Employee deep acting anova table

\begin{tabular}{|c|c|c|c|c|c|c|}
\hline \multicolumn{7}{|c|}{ Anova $^{c}$} \\
\hline Model & & $\begin{array}{c}\text { Sum of } \\
\text { Squares }\end{array}$ & $\mathrm{df}$ & $\begin{array}{l}\text { Mean } \\
\text { Square }\end{array}$ & $\mathrm{F}$ & Sig. \\
\hline \multirow[t]{4}{*}{1} & Regressio & 4.922 & 2 & 2.461 & 12.73 & $.000^{\mathrm{a}}$ \\
\hline & & & & & 1 & \\
\hline & Residual & 15.465 & 160 & .193 & & \\
\hline & Total & 20.387 & 162 & & & \\
\hline \multirow[t]{4}{*}{2} & Regressio & 5.546 & 3 & 1.849 & 9.841 & $.000^{\mathrm{b}}$ \\
\hline & & & & & & \\
\hline & Residual & 14.841 & 159 & .188 & & \\
\hline & Total & 20.387 & 162 & & & \\
\hline
\end{tabular}

a. Predictors: (Constant), Customer perceptions of employee deep acting, employee deep acting 。

b. Predictors: (Constant), Customer perceptions of employee deep acting, employee deep acting。A1。

c. Dependent Variable: Perceived customer orientation

As can be seen from Table2, constant term of model 1 in the regression model was significant $(\mathrm{B}=1.837, \mathrm{t}=5.024, \mathrm{P}=0.000 \leq 0.05)$;Employee deep acting relates positively to perceived customer orientation $(\mathrm{B}=0.287, \mathrm{t}=3.193, \mathrm{P}=0.002 \leq 0.05)$; Customer perceptions of employee deep acting relates negatively to perceived customer orientation $(B=0.207, t=2.201, P=0.031 \leq 0.05)$. Constant term of model 2 in the regression model was significant $(\mathrm{B}=-0.385, \mathrm{t}=-0.303, \mathrm{P}=0.763 \geq 0.05)$; Employee deep acting relates positively to perceived customer orientation $(\mathrm{B}=0.930, \mathrm{t}=2.557, \mathrm{P}=0.012 \leq 0.05)$; Customer perceptions of employee deep acting relates negatively to perceived customer orientation $(\mathrm{B}=0.890, \mathrm{t}=2.307, \mathrm{P}=0.024 \leq 0.05)$. Interaction term $\mathrm{A} 1$ doesn't relate negatively to perceived customer orientation $(B=-0.194, t=-1.823, P=0.0723 \geq 0.05)$.

This shows the regulation of customer perceptions of employee deep acting is not obvious .That is to say, it does not hold hypothesis $3 \mathrm{a}$.Therefore, we reject the hypothesis $3 \mathrm{a}$.

Tab2 Perceived customer orientation and Employee deep acting coefficients table

\begin{tabular}{|c|c|c|c|c|c|}
\hline \multirow[t]{2}{*}{ Modle } & \multicolumn{2}{|c|}{$\begin{array}{l}\text { Unstandardized } \\
\text { coefficients }\end{array}$} & \multirow{2}{*}{$\begin{array}{c}\text { Standardized } \\
\text { coefficients } \\
\text { Beta }\end{array}$} & \multirow[t]{2}{*}{$\mathrm{t}$} & \multirow[t]{2}{*}{ Sig. } \\
\hline & B & Error & & & \\
\hline (Constand) & 1.837 & .366 & & 5.024 & .000 \\
\hline employee deep acting & .287 & .090 & .343 & 3.193 & .002 \\
\hline $\begin{array}{r}\text { Customer perceptions of } \\
\text { employee deep acting }\end{array}$ & .207 & .094 & .236 & 2.201 & .031 \\
\hline (Constand) & -.385 & 1.271 & & -.303 & .763 \\
\hline employee deep acting & .930 & .364 & 1.111 & 2.557 & .012 \\
\hline $\begin{array}{l}\text { Customer perceptions of } \\
\text { employee deep acting }\end{array}$ & .890 & .386 & 1.014 & 2.307 & .024 \\
\hline A1 & -.194 & .107 & -1.315 & -1.823 & .072 \\
\hline
\end{tabular}

a. Dependent Variable: Perceived customer orientation

(2) The relation between perceived service quality and Employee deep acting- Customer perceptions of employee deep acting as the moderator

Take perceived service quality as the dependent variable, and regression analysis employee deep acting, Customer perceptions of employee deep acting, and the two interaction terms, we have two models. As can be seen from Table3, the average error of a regression model 1 is 4.836, $\mathrm{F}$ value of 19.450, $\mathrm{P}$ value close to 0 ; The average error of a regression model 2 is $3.233, \mathrm{~F}$ value of $12.862, \mathrm{P}$ value close to 0 ; This means that it is suitable for regression analysis of "Customer perceptions of 
employee deep acting" and "perceived service quality" and "deep acting", and the two models have passed the hypothesis testing.

Tab3 Perceived service quality and Employee deep acting anova table

\begin{tabular}{|c|c|c|c|c|c|c|}
\hline \multicolumn{7}{|c|}{$\operatorname{Anova}^{c}$} \\
\hline \multicolumn{2}{|c|}{ Model } & $\begin{array}{c}\text { Sum of } \\
\text { Squares }\end{array}$ & df & Mean Square & $\mathrm{F}$ & Sig. \\
\hline \multirow[t]{3}{*}{1} & Regression & 9.671 & 2 & 4.836 & 19.450 & $.000^{\mathrm{a}}$ \\
\hline & Residual & 19.889 & 160 & .249 & & \\
\hline & Total & 29.560 & 162 & & & \\
\hline \multirow[t]{3}{*}{2} & Regression & 9.700 & 3 & 3.233 & 12.862 & $.000^{\mathrm{b}}$ \\
\hline & Residual & 19.860 & 159 & .251 & & \\
\hline & Total & 29.560 & 162 & & & \\
\hline
\end{tabular}

a. Predictors: (Constant), Customer perceptions of employee deep acting, employee deep acting 。

b. Predictors: (Constant), Customer perceptions of employee deep acting, employee deep acting 。

A1。

c. Dependent Variable: Perceived service quality

As can be seen from Table4, constant term of model 1 in the regression model was significant $(\mathrm{B}=1.211 \mathrm{t}=2.921 \mathrm{P}=0.005 \leq 0.05) ;$ Employee deep acting relates positively to Perceived service quality $(\mathrm{B}=0.210, \mathrm{t}=2.059, \mathrm{P}=0.043 \leq 0.05)$;Customer perceptions of employee deep acting relates negatively to Perceived service quality $(\mathrm{B}=0.478, \mathrm{t}=4.474, \mathrm{P}=0.000 \leq 0.05)$. Constant term of model 2 in the regression model was not significant $\quad(\mathrm{B}=1.691, \mathrm{t}=1.150, \mathrm{P}=.253 \geq 0.05)$;Employee deep acting doesn't relate positively to Perceived service quality ( $\mathrm{B}=0.071, \mathrm{t}=0.168$, $\mathrm{P}=0.867 \geq 0.05$ ) ;Customer perceptions of employee deep acting doesn't relate negatively to Perceived service quality $(\mathrm{B}=0.331, \mathrm{t}=0.741, \mathrm{P}=0.461 \geq 0.05)$.Interaction term $\mathrm{A} 1$ doesn't relate negatively to Perceived service quality（ $\mathrm{B}=0.042, \mathrm{t}=0.341, \mathrm{P}=0.734 \geq 0.05$ ）。

This shows the regulation of Customer perceptions of employee deep acting is not obvious .That is to say, it does not hold hypothesis $3 \mathrm{~b}$. Therefore, we reject the hypothesis $3 \mathrm{~b}$.

Tab4Perceived service quality and Employee deep acting coefficients table

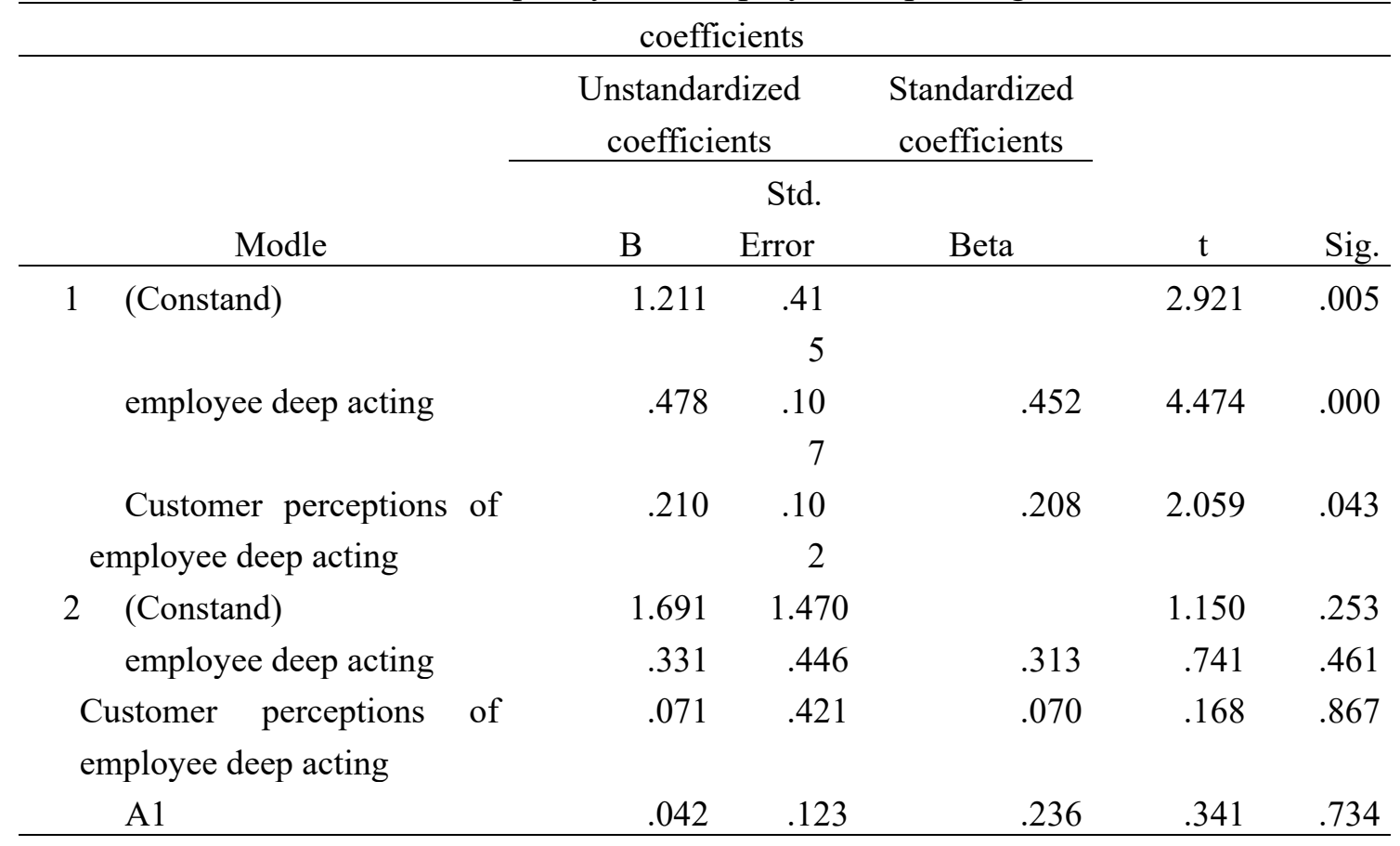

a. Dependent Variable: Perceived service quality

(3) The relation between Perceived customer orientation and employee surface acting - Customer 
perceptions of employee surface acting as the moderator

Take Perceived customer orientation as the dependent variable, and regression analysis employee surface acting, Customer perceptions of employee surface acting, and the two interaction terms, we have two models. As can be seen from Table5, the average error of a regression model 1 is $0.294, \mathrm{~F}$ value of $19.450, \mathrm{P} P=0.3103 \geq 0.05$; The average error of a regression model 2 is $3.353, \mathrm{~F}$ value of $12.441, \mathrm{P}=0.037 \leq 0.05$; This means that it is suitable for regression analysis of "Customer perceptions of employee surface acting" and "Perceived customer orientation" and "surface acting", and only Model 2 goes through hypothesis testing.

Tab5 Perceived customer orientation and employee surface acting anova table

\begin{tabular}{|c|c|c|c|c|c|c|}
\hline \multicolumn{7}{|c|}{ Anova $^{c}$} \\
\hline & \multirow[b]{2}{*}{ Model } & \multirow{3}{*}{$\begin{array}{c}\begin{array}{c}\text { Sum of } \\
\text { Squares }\end{array} \\
.588\end{array}$} & \multirow{3}{*}{$\frac{\mathrm{df}}{2}$} & \multirow{3}{*}{$\begin{array}{r}\begin{array}{r}\text { Mean } \\
\text { Square }\end{array} \\
.294\end{array}$} & \multirow{3}{*}{$\frac{F}{1.189}$} & \multirow{3}{*}{$\frac{\text { Sig. }}{.310^{\mathrm{a}}}$} \\
\hline & & & & & & \\
\hline 1 & Regression & & & & & \\
\hline & Residual & 19.799 & 160 & .247 & & \\
\hline & Total & 20.387 & 162 & & & \\
\hline \multirow[t]{3}{*}{2} & Regression & 1.058 & 3 & 3.353 & 12.441 & $.037^{\mathrm{b}}$ \\
\hline & Residual & 19.329 & 159 & .245 & & \\
\hline & Total & 20.387 & 162 & & & \\
\hline
\end{tabular}

a. Predictors: (Constant), Customer perceptions of employee surface acting, employee surface acting.

b. Predictors: (Constant), Customer perceptions of employee surface acting, employee surface acting. A2.

c. Dependent Variable: Perceived customer orientation

As can be seen from Table6, constant term of model 1 in the regression model was significant $(\mathrm{B}=3.673, \mathrm{t}=14.796, \mathrm{P}=0.000 \leq 0.05)$; Employee surface acting doesn't relate positively to Perceived customer orientation $(\mathrm{B}=0.096, \mathrm{t}=1.308, \mathrm{P}=0.195 \geq 0.05)$;Customer perceptions of employee surface acting doesn't relate negatively to Perceived customer orientation $(B=-0.098, t=-1.281$, $\mathrm{P}=0.2045 \geq 0.05$ );

Constant term of model 2 in the regression model was significant $(B=4.684, t=6.079$, $\mathrm{P}=0.000 \leq 0.05)$; Employee surface acting relates positively to Perceived customer orientation $(\mathrm{B}=-0.293, \mathrm{t}=-3.010, \mathrm{P}=0.015 \leq 0.05)$; Customer perceptions of employee surface acting relates negatively to Perceived customer orientation $(\mathrm{B}=-0.432, \mathrm{t}=-2.708, \mathrm{P}=0.042 \leq 0.05)$. Interaction term $A 2$ relates negatively to Perceived customer orientation $(\mathrm{B}=0.125, \mathrm{t}=2.385, \mathrm{P}=0.040 \leq 0.05)$ 。

This shows the regulation of Customer perceptions of employee surface acting is obvious .That is to say, it holds hypothesis $4 \mathrm{a}$. Therefore, we reject the hypothesis $4 \mathrm{a}$. 
Tab6 Perceived customer orientation and employee surface acting coefficients table

\begin{tabular}{|c|c|c|c|c|c|}
\hline \multicolumn{6}{|c|}{ coefficients } \\
\hline \multirow[t]{2}{*}{ Modle } & \multicolumn{2}{|c|}{$\begin{array}{c}\text { Unstandardized } \\
\text { coefficients } \\
\end{array}$} & \multirow{2}{*}{$\begin{array}{c}\text { Standardized } \\
\text { coefficients } \\
\text { Beta } \\
\end{array}$} & \multirow[t]{2}{*}{$\mathrm{t}$} & \multirow[b]{2}{*}{ Sig. } \\
\hline & B & Std. Error & & & \\
\hline (Constand) & 3.673 & .248 & & 14.796 & .000 \\
\hline employee surface acting. & .096 & .073 & .158 & 1.308 & .195 \\
\hline $\begin{array}{l}\text { Customer perceptions of } \\
\text { employee surface acting, }\end{array}$ & -.098 & .076 & -.155 & -1.281 & .204 \\
\hline (Constand) & 4.684 & .771 & & 6.079 & .000 \\
\hline employee surface acting. & -.293 & .290 & -.483 & -3.010 & .015 \\
\hline $\begin{array}{l}\text { Customer perceptions of } \\
\text { employee surface acting, }\end{array}$ & -.432 & .253 & -.684 & -2.708 & .042 \\
\hline $\mathrm{A} 2$ & .125 & .090 & .997 & 2.385 & .040 \\
\hline
\end{tabular}

a. Dependent Variable: Perceived customer orientation

(4) The relation between Perceived service quality and employee surface acting - Customer perceptions of employee surface acting as the moderator

Take Perceived service quality as the dependent variable, and regression analysis employee surface acting, Customer perceptions of employee surface acting, and the two interaction terms, we have two models. As can be seen from Table7, the average error of a regression model 1 is $0.775, \mathrm{~F}$ value of $2.212, \mathrm{P}=0.3103 \geq 0.05$; So that the model 1 is not suitable for a regression analysis; The average error of a regression model 2 is $1.269, \mathrm{~F}$ value of $3.893, \mathrm{P}=0.012 \leq 0.05$; This means that it is suitable for regression analysis of "Customer perceptions of employee surface acting" and "Perceived service quality" and "surface acting", and only Model 2 goes through hypothesis testing.

Tab7 Perceived service quality and employee deep acting anova table

\begin{tabular}{cllllrr}
\hline & \multicolumn{7}{c}{ Anova $^{\mathbf{c}}$} \\
\hline & Model & Sum of Squares & df & Mean Square & F & Sig. \\
\hline 1 & Regression & 1.549 & 2 & .775 & 2.212 & $.116^{\mathrm{a}}$ \\
& Residual & 28.011 & 80 & .350 & & \\
& Total & 29.560 & 82 & & \multirow{2}{*}{3.893} & $.012^{\mathrm{b}}$ \\
2 & Regression & 3.808 & 3 & 1.269 & & \\
& Residual & 25.753 & 79 & .326 & & \\
& Total & 29.560 & 82 & &
\end{tabular}

a. Predictors: (Constant), Customer perceptions of employee deep acting, employee deep acting.

b. Predictors: (Constant), Customer perceptions of employee deep acting, employee deep acting. A2。

c. Dependent Variable: Perceived service quality

As can be seen from Table8, constant term of model 1 in the regression model was significant $(\mathrm{B}=4.106, \mathrm{t}=13.906, \mathrm{P}=0.000 \leq 0.05) ;$ Employee surface acting doesn't relate positively to Perceived service quality $(\mathrm{B}=0.065, \mathrm{t}=0.745, \mathrm{P}=0.4583 \geq 0.05)$; Customer perceptions of employee surface acting relates negatively to Perceived service quality $(\mathrm{B}=-0.191, \mathrm{t}=-2.100, \mathrm{P}=0.039 \leq 0.05)$; Constant term of model 2 in the regression model was significant $(B=6.324, t=7.110, P=0.000 \leq 0.05)$; Employee surface acting relates positively to Perceived service quality $(\mathrm{B}=-0.925, \mathrm{t}=-3.163, \mathrm{P}=0.002 \leq 0.05)$; Customer perceptions of employee surface acting relates negatively to Perceived service quality $(\mathrm{B}=-0.925, \mathrm{t}=-3.163, \mathrm{P}=0.002 \leq 0.05)$. Interaction term $\mathrm{A} 2$ relates negatively to Perceived service quality（ $\mathrm{B}=0.274, \mathrm{t}=2.632, \mathrm{P}=0.010 \leq 0.05$ ）。

This shows the regulation of Customer perceptions of employee surface acting is obvious .That is to say, it holds hypothesis $4 \mathrm{~b}$. Therefore, we accpet the hypothesis $4 \mathrm{~b}$. 
Tab 8Perceivedservice quality and employee surface acting coefficients table

\begin{tabular}{|c|c|c|c|c|c|c|}
\hline \multicolumn{7}{|c|}{ coefficients } \\
\hline & \multirow[t]{2}{*}{ Modle } & $\begin{array}{r}\text { Unstan } \\
\text { coeff }\end{array}$ & $\begin{array}{l}\text { rdized } \\
\text { ents }\end{array}$ & $\begin{array}{l}\text { Standardize } \\
\mathrm{d} \\
\text { coefficients }\end{array}$ & $\mathrm{t}$ & \multirow[b]{2}{*}{ Sig. } \\
\hline & & B & $\begin{array}{l}\text { Std. } \\
\text { Error }\end{array}$ & Beta & & \\
\hline 1 & (Constand) & 4.106 & .295 & & 13.906 & .000 \\
\hline & employee surface acting. & .065 & .087 & .089 & .745 & .458 \\
\hline & $\begin{array}{l}\text { Customer perceptions of } \\
\text { employee surface acting, }\end{array}$ & -.191 & .091 & -.251 & -2.100 & .039 \\
\hline 2 & (Constand) & 6.324 & .889 & & 7.110 & .000 \\
\hline & employee surface acting. & -.789 & .335 & -1.078 & -2.354 & .021 \\
\hline & $\begin{array}{l}\text { Customer perceptions of } \\
\text { employee surface acting, }\end{array}$ & -.925 & .292 & -1.215 & -3.163 & .002 \\
\hline & A2 & .274 & .104 & 1.815 & 2.632 & .010 \\
\hline
\end{tabular}

\section{Conclusion}

Known from the analysis of data, the relationship between service personnel emotional labor and customers reaction can be summarized as follows:(1) Employee deep acting relates positively to perceived customer orientation; (2) Employee deep acting relates positively to perceived service quality; (3) The greater customers' surface acting detection accuracy, the more strongly negative the relationship between employee surface acting and perceived service quality; (4 Perceived customer orientation relates positively to perceived service quality;(5) Perceived customer orientation relates positively to customer loyalty intentions;@ Perceived service quality relates positively to customer loyalty intentions; (7) The greater customers' surface acting detection accuracy, the more strongly negative the relationship between employee surface acting and perceived customer orientation.

However, some assumption does not hold, thus:(1) Employee surface acting doesn't relate negatively to perceived customer orientation;(2) Employee surface acting doesn't relate negatively to perceived service quality; (3) The greater customers' deep acting detection accuracy, there isn't more strongly positive the relationship between employee deep acting and perceived customer orientation. (4) The greater customers' deep acting detection accuracy, there isn't more strongly positive the relationship between employee deep acting and perceived service quality.

\section{References}

[1]Grandey, A. A. (2003). When "the show must go on":Surface and deep acting as predictors of emotional exhaustion and service delivery. Academy of Management Journal, 46, 86-96.

[2]Glomb, T. M., Kammeyer-Mueller, J. D., \& Rotundo, M.(2004). Emotional labor demands and compensating wage differentials. Journal of Applied Psychology, 89, 700-714.

[3]Chau, S. L., Dahling, J. J., Levy, P. E., \& Diefendorff, J. M.(2009). A predictive study of emotional labor and turnover. Journal of Organizational Behavior, 30, 1151-1163.

[5] Markus, Groth. Customer Reactions to Emotional Labor: The Roles of Employee Acting Strategies and Customer Detection Accuracy, Academy of Management Journal2009, Vol.52,No.5, 958-974 